\title{
WHERE DOES CORPORATE SOCIAL RESPONSIBILITY STAND IN RELATION TO SUSTAINABILITY?
}

\author{
Nancy Diana Panța \\ Faculty of Economic Sciences, Lucian Blaga University of Sibiu, Sibiu, Romania \\ nancy.panta@ulbsibiu.ro
}

\begin{abstract}
The business competitive landscape of today is shaped by new challenges. In order to outperform their peers, companies seek to seize opportunities and manage the risks associated with the challenges that arise. To this adds the pressure of societies on organizations to be more transparent, ethical and responsible. Corporate Social Responsibility (CSR) and sustainability come in response to this increasing demand of societies by being a pivotal tool in the business area. Organizations of the $21^{\text {st }}$ century can no longer ignore CSR and sustainability and should follow the steps of integrating them across all departments as part of their strategic policy. Sustainable organizations are required to direct their interest beyond the economical factor and extend their goals towards environmental and social aspects. By integrating environmental and social concerns in the daily operations of a company, new models of doing business emerge and a synergy with various stakeholder groups takes place. Although a significant amount of attention has been headed towards the conceptualisation of CSR and sustainability, they both remain contested concepts. Therefore, the present paper depicts the effort to follow the emergence and conceptualization of CSR and sustainability from their origins, to introduce the changing meaning of CSR and to bridge the gap between the two concepts. Through literature review, the paper will provide relevant theoretical underpinnings that link CSR and sustainability.
\end{abstract}

Keywords: Corporate Social Responsibility, Sustainability, Stakeholders, Theoretical Framework

JEL classification: Q01, M14

\section{Introduction}

Throughout the world, organisations of today are aware of the new role they have, which is to meet the needs of the present generation without harming the potential of future generations to meet theirs. The business environment, and especially the large corporations sector, is now considered to play a major role in taking action in order to reach progress in the field of sustainable development. To this adds the way a company manages to maintain good quality relationships with its employees, but also with its other stakeholders.

The concept of Corporate Social Responsibility (CSR) has managed to attract significant attention not only from scholars and governmental representatives, but also from practitioners that aim to move their organisations towards more than what involves transparency and ethical behaviour. Moreover, new sustainable business models emerge as a way to counter shortfalls at governance, societal and environmental level.

Taken together, both CSR and sustainability are considered one of the main drivers for businesses and numerous organizations have embraced the challenges that CSR and sustainable development brought.

Still, it appears that the two topics lack comprehension among executive managers of companies and raise discussions (Juscius, 2007). Therefore, the present paper will follow to synthesize the knowledge in the fields of CSR and sustainability and determine the link between the two. 


\section{Corporate Social Responsibility - Emergence}

Although CSR has gained more attention from academics and practitioners in the last decades, it is not a new field of study. The origins of CSR date back to the early twentieth century, when capitalism consolidation occurred. Whether a company should undertake both economic and social functions sparked interest at the time to Weber (1922) and Clark (1939). They are considered to be the initial contributors in the field and began the search of denoting the possibility of company executives to achieve a management model that is competitive though responsible economic actions.

Still, the first work about social responsibility belongs to Bowen (1953), considered the founder of the concept, who defined social responsibility as 'the set of moral and personal obligations that the employer must follow, considering the exercise of policies and values desired by society'. Since the fifties, there has been consciousness that companies can impact the lives of citizens and that firms should positively act upon their main social and economic imbalances. Thus, considering the social function together with the economic function in a firm has been underlined.

Social responsibility as a research topic began to gain interest from others since Bowen's work. Drucker (1954) acknowledged the need to consider public opinion in the decision making process of an organization, especially in the case of large companies which are operating in scenarios of social pressure.

Davis (1960) noted that the interests of those parties affected by organizational actions need firm's attention in order to gain support from them. He considered that the organizations that do not worry about the impact of their actions upon the environment might cease to benefit of their stakeholders' trust, which eventually causes the success of a business.

Walton (1967) introduces the idea that social responsibility is voluntary for a business and that its implementation involves relationship improvement with the stakeholders, but also an acceptance of a cost and risk. Other researchers (Wallich and Mcgowan, 1970) stated that the economic and social interests of stakeholders must be balanced by companies.

During the fifties, sixties and seventies social responsibility was referred to as an adjustment process among the business operating environment and the stakeholders, while in the eighties the theoretical dispersion of the concept began to emerge.

A significant amount of work in the field of social responsibility was done by authors who reacted in response to the players that have a stake in the business performance, and led to what is known as stakeholders theory. Freeman (1984) introduced the stakeholder concept, while the power and claims that each party has on the company have been later investigated (Mitchell et al., 1997). The stakeholder concept involves that the firm establishes relationships both with relevant groups, such as owners and shareholders, and alternative parties (suppliers, government, customers, employees, investors, local community, unions, competitors, media) (Bridoux and Stoelhorst, 2014).

The CSR concept is diversified and has been changing over time until today. According to Carroll (1991), CSR theory takes into account four levels built up on a pyramid: economic responsibility, such as being profitable; duty to obey the law; responsibility to be ethical and philanthropic responsibility. The model is still widely discussed today. More recently, Epstein (2008) identified nine areas in which CSR operates: ethics, governance, employment practices, transparency, business relationships, environmental protection, financial return, product value and community involvement.

There are numerous definitions in the literature regarding CSR which range from business strategic repositioning to corporate philanthropic activities (Nijhof and Jeurissen, 2010). CSR designates the way businesses implement social responsibilities by going beyond the economic factor (Khojastehpour and Johns, 2014) and involves a series of corporate activities that aim to ensure stakeholders welfare (Spinkle and Maines, 2010). Parguel and 
Benoit-Moreau (2011) defined CSR as a voluntary integration of aspects of social and environmental nature into daily business operations and stakeholder interaction.

Monetary together with non-monetary benefits of CSR initiatives have been determined by scholars. A well built CSR strategy leads to a strong position in the market (Smith, 2003), which further enables companies to gain competitive advantage (Carroll et al., 2010).

CSR acts in favour of an augmented customer relationship, increases customers loyalty (Pivato et al., 2008) and attracts external investments, as investors seek companies that have not damaged their company ethics (Smith, 2003). CSR is considered a proactive process which enables an organization to exercise more leverage over other organizations (Carroll et al., 2010) and its initiatives may determine a business' image and reputation, increase its sales revenue and improve employee engagement (Radhakrishnan et al., 2014).

On the other hand, since modern businesses operate in a competitive environment, their stakeholders have expectations of them performing with minimal financial contraction, which is why CSR has also attracted averse opinions. Thus, the earliest resistant argument includes the co-existence of business and CSR in the context of profit maximization (Friedman, 1970) further discussed as the business not focusing on its core functions, but on non-core functions (Radhakrishnan et al., 2014). Moreover, Visser (2011) criticizes the success of CSR, primarily at the macro level, since environmental and social indicators are declining (biodiversity loss, gap between rich and poor), although there have been improvements at the micro level.

Scholars have also identified the reasons why CSR is implemented in daily business operations and these include customer-related motivations; altruistic intentions; firm's appearance improvement in order to acceding to various stakeholders demands or obtaining employee recruitment and retention benefits (Sprinkle and Maines, 2010). These reasons emerge into a rationale why CSR exists, which is that organizations need to be managed in order to create values and to satisfy the interests of its main stakeholders (Freeman et al., 2010).

MacGregor et al. (2008) outline that CSR implementation can be a starting point in the field of proactive innovation and that it constitutes a guide mark for companies that wish to improve their position in the market, but are typically risk-averse.

The new tendencies on ethical consumption indicate that individuals are more than only consumers, being responsible for the choices they make when purchasing (Vitell, 2015). These led to the new construct of Personal Social Responsibility (PSR), as a key element to upgrade CSR, that integrates ethical/responsible consumption (Lopez Davis et al., 2017). So far, it has been established that CSR focuses on the relationship between business and the general public. In addition, PSR focuses on the behaviour of the individual, stressing the effects its daily decisions have on its social and ecological environment (Lopez Davis et al., 2017). Not only companies will aim for better relationships with their stakeholders through responsible behaviours, but also individuals, who will make decisions based on pursuing greater relationships with their stakeholders (families, community).

Criticism of CSR has also emerged. Banarjee (2007), Mullerat (2009) or Heath (2010) argue that the CSR concept is a rhetoric and an empty promise of delivering more than public relations benefits. Others (Aras et al., 2010) note that the manner in which companies are engaged in CSR-related activities is minimal as compared to the level of publicity for the efforts. Visser (2011) also criticizes CSR and notes that the raison d'être of business is to be in the service of society, in a positive way. This conception unfolds Corporate Social Responsibility, or CSR 1.0 to the new, diversified and integrated Corporate Sustainability and Responsibility, or CSR 2.0. 


\subsection{Practitioners approach of CSR}

In a survey led by Economist Intelligence Unit (2008), 1,254 executives around the world participated, with 53\% from firms having at least US\$500m in revenue. The results showed that 53.5 percent of respondents said that CSR is 'a necessary cost of doing business'; 53.3 percent agreed that it 'gives a distinctive position in the market' and 3.8 percent thought that CSR was 'a waste of time and money'.

CSR has also received attention from institutions, initiatives and bodies such as the European Commission (2001) which published the Green Book of CSR, World Business Council For Sustainable Development (WBCSD) or Global Reporting Initiative. Although focused on sustainable development, WBCSD (1999) has identified CSR as a constituent component of sustainability and has defined it as the "commitment of business to contribute to sustainable economic development, working with employees, their families, the local community and society at large to improve their quality of life'.

Nowadays, various international organizations, such as European Union, Organisation for Economic Co-operation and Development and International Labour Organization have emphasized the importance of CSR adoption and exhibited a series of ethical and social guidelines. Consequently, organizations that aim to be sustainable cannot ignore CSR any more.

\section{Sustainability in the Business Environment}

The idea of sustainability has its origins back to the eighteen century being used in forestry. At the time, a quota limited the number of trees that were being cut in order to ensure a sufficient amount of wood supply that would not affect the resources of the forthcoming generations. After the Second World War, the level of awareness of the existing and potential damages upon the ecosystem increased, which led to the establishment of the United Nations Organization in 1945. The organization has worked towards achieving global sustainable development, along with encouraging cross-cultural dialogue, maintaining peace and providing humanitarian aid.

In 1987, the World Commission on Environment and Development published the Brundtland report, named after the former Norwegian prime-minister, which defined sustainable development. The published work was debated in the United Nations General Assembly and referred to satisfying the human needs (shelter, food, clothing) and aspirations (job, improved quality of life). Sustainable development has been defined in the Brundtland report as an ethical concept and "a development that meets the needs of the present without compromising the ability of future generations to meet their own needs" (World Commission on Environment \& Development, 1987). There has been an eco-development approach given to the sustainability concept, that is consistent with the environment and resources (Ebner and Baumgartner, 2006). This has led to their protection and to the mission statement of today's sustainability.

Since the Brundtland report was published, other works in the area of sustainable development began to emerge. There has been a focus on companies, and Elkington (1998) wrote that they should not only aim for profit maximisation, but also concentrate on social and environmental issues to the same extent. This approach has developed into what is known as a model of triple-bottom line, meaning that sustainability includes social, environmental and economic dimensions (United Nations Sustainable Development, 1992) which should be treated equally, integrated and balanced as components that support sustainable development (United Nations General Assembly, 2002).

Still, literature has lacked publications in the field of sustainability in the early years of emergence, and only since 2003 there were works published annually (Silveira and Petrini, 2017). Afterwards, since 2009, the number of works related to sustainability increased noticeably reaching roughly 20 publications per year, while the amount of work published 
from 2009 to 2015 accounts for $78 \%$ of works written on the theme (Silveira and Petrini, 2017).

Ethical values lie at the base of sustainability. Sustainability works towards meeting the needs of the majority of the people (United Nations, 1992), while giving priority to the vulnerable ones that find themselves in special social and environmental situations.

Since the first mention of sustainability, it took several years to commit into practically working towards a sustainable future. Therefore, starting January 2016, United Nations has launched a universal call to action with the aim of improving the lives of future generations through 17 goals, also known as Sustainable Development Goals. The Sustainable Development Goals serve as a handbook and objective for all countries and are included in the Sustainable Development Agenda 2030.

Each goal has a specific target to be reached and in order to achieve that, multiple parties, such as governments, the private sector and citizens need to get together and bring their contribution. The Sustainable Development Goals address aspects such as poverty and hunger eradication, good health and well-being, quality education, gender equality, clean water and sanitation, affordable and clean energy, decent work and economic growth, innovation, reduced inequalities, sustainable communities, responsible production and consumption, climate action, life below water and on land, peace, justice and partnership for the goals (United Nations, 2016).

The 2030 Agenda recognizes the role of the business environment in contributing to sustainable development and starting 2016 it organized the Sustainable Development Goals Business Forum with the aim of better understanding the links between social values and business efforts to improve the quality of life in the local communities and obtain long term bottom line benefits. More than that, it even developed a guide for businesses on how to implement them (United Nations, 2015) also known as the Sustainable Business Goals Compact. The aim of the guide is to provide support to companies on aligning their strategies with the path of sustainable development and help measure and manage their contribution. It involves five steps: understanding the Sustainable Development Goals, defining priorities, setting goals, integrating, and reporting and communicating. Although it is developed with a focus on large enterprises, small and medium enterprises are also encouraged to use it and adapt it accordingly.

The European Union has also recognized the role of sustainability and its importance and committed to monitor the evolution of Sustainable Development Goals throughout the Community in areas such as reliable food production, climate change, sustainable management of natural resources and balanced development among community members. When relating sustainability to the business environment, it appears that the operationalisation of the notion remains inconsistent (Özkaynak et al., 2004), in spite of an increased attention in the speciality literature. Dyllick and Hockerts (2002) are among the authors that have shown interest to the field of business sustainability and have defined it as 'satisfying the direct and indirect needs of stakeholders of a firm without compromising firm's future abilities to satisfy the needs of stakeholders'. Such approach has led to the necessity of other business infrastructures such as new business models and sustainability related practices (Dyllick and Hockerts, 2002) that need to be integrated and connected (Rocha et al., 2007).

In terms of economic paradigms related to sustainability, literature suggests that there are several that can be distinguished. Business sustainability 1.0 evolves from the traditional economic paradigm that only seeks to obtain economic benefits (profits, market share) through minimal costs or efficient processes, and addresses social and environmental issues (Dyllick and Muff, 2015). However, firm's objectives remain headed towards the value creation for shareholders. With a more extended view that not only includes shareholders but also social and environmental aspects, is business sustainability 2.0 that aims for sustainability through specific programs that have their evolution monitored. Furthermore, 
business sustainability 3.0 brings businesses even closer to sustainability through a series of key elements that look to address sustainability issues in the society through their products and services. Consequently, this new paradigm approaches society's challenges of environmental and social nature and conveys them into business opportunities (Dyllick and Muff, 2015).

Although during the last decades, practitioners and scholars expressed interest in the field of sustainability there is still a lack of understanding on how organizations can successfully implement it.

\subsection{Practitioners approach of Sustainability}

Nonetheless, efforts have been made over the last years by practitioners, in particular, to help facilitate businesses direction on the path of sustainability. Such efforts include the activity of World Business Council for Sustainable Development (WBCSD) which gathers more than 200 major businesses that collaborate with the aim of reaching success by considering sustainability, Global Reporting Initiative (GRI) that contributes to a better understanding of sustainability through the GRI Standards or International Standards Organization (ISO) which offers guidance on sustainability matters though ISO 26000.

\section{Bringing Sustainability and Corporate Social Responsibility together}

Defining widely the concepts of CSR and sustainability has led to various understandings and has attached extra complexity to the terms, especially when used together (Ebner and Baumgartner, 2006). However, the emergence of terms helps filling the gap. Sustainability rooted in the Brundtland report with a social, economic and environmental triple bottom line, while CSR is approached from a social and stakeholders perspective within the organization.

Also, as an active party in the field of sustainability, WBCSD refers to CSR as a constituent of the social dimension of sustainability that supports organisations in being good corporate citizens. Moreover, it considers CSR as "business'commitment to contribute to sustainable economic development, working with employees, their families, the local community, and the society at large to improve their quality life" (WBCSD, 2006).

Some argue that CSR is viewed as part of sustainability (Bhagwat, 2011). However, due to inconsistencies in the operationalisation of the concepts, it is not clear where CSR is exactly incorporated.

Thus, the two concepts have also been overlapped and used synonymously (EImualim, 2017) where CSR is considered a voluntary action of public interest integrated into the decision making of a process of corporations that honours the triple bottom line of People, Planet and Profit.

Measuring the progress of CSR and sustainability has been a continuous challenge for both scholars and practitioners. Still, a series of indices, also referred to as benchmarks, were developed over the last years with the objective to describe the situation of companies meeting certain requirements. The reasons for establishing such instruments include the creation of benchmark for companies involved in CSR and sustainability activities, as well as a reference for investors that consider their investment decisions based on such aspects. Various frameworks and indices appear to integrate sustainability and CSR dimensions and the major ones include the Global Reporting Initiative (GRI), Dow Jones Sustainability Index (DJSI), ARESE Sustainability Performance Indices (ASPI) or FTSE4GOOG Indices.

The GRI Standards provide the means for companies to measure and present information about their performance through Universal Standards or Topic-Specific Standards. GRI is a free public good which is being used in more than 90 countries by thousands of organizations and was launched in the 1990s. It is carried out voluntarily by companies covering areas such as sustainable development strategy, implementation of international 
standards for sustainable development and CSR, stakeholder engagement, governance, environmental protection management or ethics and integrity. The DJSI was the first global index, was launched in 1999 and comprises six tracking criteria that include strategy, financial, governance and stakeholder, customer and product, human and process. The ARESE Sustainability Performance Indices launched in 2001 and track companies performance of four criteria: triple bottom line, positive screening approach, risk management and a stakeholder-centred approach. FTSE4GOOD Indices measures the performance of companies around the world being launched in 2001 by London Stock Exchange. It undergoes both a negative selection that excludes those companies dealing with weapons production, substance production or violating social equality principles, and a positive selection that covers environmental sustainability, stakeholder relationships and universal human rights.

\section{Conclusion}

To harness opportunities, organizations have widely adopted CSR and sustainability practices. Embedding the two constructs enables firms to connect with their stakeholders, contribute to environmental protection and obtain increased profits, generating a virtuous circle of multiple positive effects (Camilleri, 2017). Both strategic in purposes, CSR and sustainability provide an ethical framework that benefit organizations in the long term. The CSR areas identified by Epstein (2008) include the triple bottom line of sustainability, while others (Bhagwat, 2001) discuss about CSR as a constituent part of sustainability. Moreover, various indices such as Global Reporting Initiative, refer to CSR and sustainability aspects separately, while WBCSD considers CSR as a component of the social dimension of sustainability that contributes to a better corporate citizenship. Nonetheless, one of the most well-known frameworks of CSR until now probably remains the Pyramid of CSR proposed by Carroll (1991) created on four definitional parts: economic, legal, ethical, and philanthropic expectations that society has of organizations. While the triple bottom line approach suggests sustainability as being the balance between three pillars: environmental, economic and social, CSR could be seen as part of the social dimension of sustainability. However, both CSR and sustainability have been and still are ongoing concepts where different approaches continue to emerge. Thus, the link between CSR and sustainability still remains unsettled due to the contested nature of the concepts, which highlights once again the need for a common basis in their conceptualisation.

\section{Acknowledgements}

This material is based on paper presented at Oradea Doctoral Symposium in Economic Sciences 2017 and represents an extended version of it.

\section{References}

Antošová, M. and Csikósová, A., 2015. Influence of European Union policy to Corporate Social Responsibility, Procedia Economics and Finance, 23, October, pp. 733-737.

Aras, G., Crowther, D., 2010. A Handbook of Governance and Social Responsibility, Gower Publishing, UK.

Banarjee., S. B., 2007. Corporate Social Responsibility: the good, the bad and the ugly. Edward Elgar Publishing, UK.

Barrena Martínez, J., López Fernández, M. and Romero Fernández, P. M., 2016. Corporate social responsibility: Evolution through institutional and stakeholder perspectives, European Journal of Management and Business Economics, 25(1), pp. 8-14. 
Behringer, K., 2016. The Role Of CSR In Achieving Sustainable Development - Theoretical Approach, European Scientific Journal, 12, pp. 10-25.

Bhagwat, P., 2011. Corporate Social Responsibility and Sustainable Development, International Journal of Academic Conference Proceedings, 1(1).

Bowen, H. R., 1953. Social responsibility of the businessman, New York: Harper \& Row.

Bridoux, F. and Stoelhorst, J. W., 2014. Microfoundations for stakeholder theory: Managing stakeholders with heterogeneous motives, Strategic Management Journal, 35, pp. 107-125. Camilleri, M. A., 2017. Corporate Sustainability and Responsibility: Creating Value for Business, Society and the Environment, Asian Journal of Sustainability and Social Responsibility, pp. 1-16.

Carroll, A. B., Shabana, K., 2010. The Business Case for Corporate Social Responsibility: A Review of Concepts, Research and Practice, International Journal of Management Reviews, 12(1), pp. 85-105.

Carroll, A. B., 1991. The pyramid of corporate social responsibility: Toward the moral management of organizational stakeholders, Business Horizons, 34(4), pp. 39-48.

Clark, C., 1939. The Marginal Productivity of Capital, Economic Record, 15, pp. 54-59.

Davis, K., 1960. Can Business Afford to Ignore Social Responsibilities? California Management Review, 2(3), pp. 70-76.

Drucker, P. F., 1954. The practice of management, New York: Harper \& Row.

Dyllick, T., Hockerts, K., 2002. Beyond the business case for corporate sustainability, Business Strategy and the Environment, 11(2), pp. 130-141.

Dyllick, T., Muff, K., 2015. Clarifying the Meaning of Sustainable Bussiness, Organization \& Environment, 29(2), pp. 156-174.

Ebner, D. and Baumgartner, R. J., 2006. The relationship between Sustainable Development and Corporate Social Responsibility, Corporate Responsibility Research Conference.

Elkington, J., 1998. Accounting for the Triple Bottom Line. Measuring Business Excellence, 2(3), pp.18-22.

Elmualim, A., 2017. CSR and sustainability in FM: Evolving practices and an integrated index, Procedia Engineering, 180, pp. 1577-1584.

Epstein, M. J., 2008. Making sustainability work: best practices in managing and measuring corporate social, environmental, and economic impacts. San Francisco: Berrett-Koehler Publishers.

Freeman, R.E., Harrison, J.S., Wicks, A.C., Parmar, B., de Colle, S., 2010. Stakeholder

Theory: The State of the Art. New York: Cambridge University Press.

Freeman, R. E., 1984. Strategic management: A stakeholder approach, Boston: Pitman.

Friedman, M., 1970. The Social Responsibility of Business is to Increase its Profits, New York Times Magazine, September 13.

Heath., R. L., 2010. The SAGE Handbook of Public Relations. New Jersey: John Wiley \& Sons.

Isa, S. M., 2012. Corporate Social Responsibility: What can we Learn from the Stakeholders? Procedia - Social and Behavioral Sciences, 65, pp. 327-337.

Juscius, V., 2007. Corporate social responsibility and sustainable development, Organizaciju vadyba: Sisteminiai tyrimai, 44, pp. 35-44.

Khojastehpour, M., Johns, R., 2014. The effect of environmental CSR issues on corporate/brand reputation and corporate profitability, European Business Review, 26(4), pp. 330-339.

Lindgreen, A., Swaen, V. and Maon, F., 2009. Corporate Social Responsibility Within the Organization, Corporate Reputation Review, 12(2), pp. 83-86.

López Davis, S., Marín Rives, L. and Ruiz de Maya, S., 2017. Introducing Personal Social Responsibility as a key element to upgrade CSR, Spanish Journal of Marketing - ESIC, 21(2), pp. 146-163. 
MacGregor, P. S. and Fontrodona, J., 2008. Exploring the Fit between CSR and Innovation, IESE Business School, University of Navarra, WP 759 . .

Mitchell, R., Agle, B., and Wood, D., 1997. Toward a Theory of Stakeholder Identification and Salience: Defining the Principle of Who and What Really Counts, The Academy of Management Review, 22(4), pp. 853-886.

Moon, J., 2007. The impact of CSR in Sustainable Development. Sustainable Development, 15, pp. 296-306.

Mousiolis, D. T. and Bourletidis, K., 2015. The Corporate Identity through the CSR's Paths, Procedia - Social and Behavioral Sciences, 175, pp. 511-514.

Mullerat, R., 2009. International Corporate Social Responsibility. Kluwer Law International, Netherlands.

Nijhof, A., Jeurissen, R., 2010. The glass ceiling of corporate social responsibility: Consequences of a business case approach towards CSR, International Journal of Sociology and Social Policy, 30(12), pp. 618-631.

Ojasoo, M., 2016. CSR reporting, stakeholder engagement and preventing hypocrisy through ethics audit, Journal of Global Entrepreneurship Research, 6(1), pp. 6-14.

Özkaynak, B., Devine, P. and Rigby, D., 2004. Operationalising Strong Sustainability: Definitions, Methodologies and Outcomes. Environmental Values, 13(3), pp. 279-303.

Parguel, B., Benoît-Moreau, F. and Larceneux, F., 2011. How Sustainability Ratings Might Deter 'Greenwashing': A Closer Look at Ethical Corporate Communication. Journal of Business Ethics, 102(1), pp.15-28.

Payne, A., 2006. Corporate social responsibility and sustainable development, Journal of Public Affairs, 6(4), pp. 286-297.

Pivato, S., Misani, N. and Tencati, A., 2008. The impact of corporate social responsibility on consumer trust: The case of organic food, Business Ethics: A European Review, 17(1), pp. 3-12.

Radhakrishnan, M. S., Chitrao, P. and Nagendra, A., 2014. Corporate Social Responsibility (CSR) in Market Driven Environment, Procedia Economics and Finance, 11(14), pp. 68-75. Rexhepi, G., Kurtishi, S. and Bexheti, G., 2013. Corporate Social Responsibility (CSR) and Innovation-The Drivers of Business Growth? Procedia - Social and Behavioral Sciences, 75, pp. 532-541.

Rocha, M., Searcy, C., Karapetrovic, S., 2007. Integrating Sustainable Development into Existing Management Systems, Total Quality Management \& Business Excellence, 18(2), pp. 83-92.

Smith, N., 2003. Corporate Social Responsibility: Whether or How? California Management Review, 54(4), pp. 52-76.

Silveira, L. and Petrini, M., 2017. Sustainable Development and Corporate Social Responsibility: a bibliometric analysis of International Scientific Production [online] Available at

http://www.scielo.br/scielo.php?pid=S0104-530X2017005007104\&script=sci arttext\&tlng= en [accessed 19.01.2018].

Šontaitè-Petkevičienè, M., 2015. CSR Reasons, Practices and Impact to Corporate Reputation, Procedia - Social and Behavioral Sciences, 213, pp. 503-508.

Sprinkle, B., Maines, G. L., 2010. The benefits and costs of corporate social responsibility, Business Horizons, 53(5), pp. 445-453.

Visser, W., 2011. The Age of Responsibility : CSR 2.0 and the New DNA of business, Journal of Business Systems, Governance and Ethics, 5(3), pp. 7-22.

Wallich, H.C, and McGowan, J., 1970. Stockholder interest and the corporation's role in social Policy, Committee for Economic Development, New York.

Walton, C., 1967. Corporate social responsibilities, Belmont: Wadsworth.

Weber, M., 1922. Economy and Society: An Outline of Interpretive Sociology, Berkley: California Press. 
World Commission on Environment and Development, 1987. Our common future, Oxford: Oxford University Press.

Dow Jones Sustainability Index, available at: http://www.sustainability-indices.com.

European Commission, available at: http://www.ec.europa.eu.

FTSE4Good Index, available at: http://www.ftse.com.

Global Reporting Initiative, available at: http://www.globalreporting.org.

International Organization for Standardization, available at: http://www.iso.org.

Sustainable Development Goals Compass, available at: http://www.sdgcompass.org

The Economist, available at: http://www.economist.com.

United Nations, available at: http://www.un.org.

United Nations Sustainable Development Knowledge Platform, available at: http://www.sustainabledevelopment.un.org.

World Business Council for Sustainable Development, available at: http://www.wbcsd.org.

\section{Bio-note}

Panța Nancy Diana is a PhD student at Lucian Blaga University of Sibiu/Faculty of Economic Sciences focused on the sustainability of organisations, currently conducting her doctoral thesis on the sustainable development of organisations in the apiary industry. 